\title{
Manufacturing and Characterization of NiTi Alloy with Functional Properties by Selective Laser Melting
}

\author{
Shih-Fu Ou ${ }^{1}$, Bou-Yue Peng ${ }^{2,3}$, Yi-Cheng Chen ${ }^{1}$ and Meng-Hsiu Tsai ${ }^{4, *}$ (i) \\ 1 Institute of Mold \& Die Engineering, National Kaohsiung University of Applied Sciences, \\ Kaohsiung 807, Taiwan; m9203510@kuas.edu.tw (S.-F.O.); smn874022000@kuas.edu.tw (Y.-C.C.) \\ 2 School of Dentistry, College of Oral Medicine, Taipei Medical University, Taipei 110, Taiwan; \\ pemg@tmu.edu.tw \\ 3 Division of Oral and Maxillofacial Surgery, Department of Dentistry, Taipei Medical University Hospital, \\ Taipei 110, Taiwan \\ 4 Casting Section, Metal Industries Research \& Development Centre, Kaohsiung 811, Taiwan \\ * Correspondence: kennytsai@mail.mirdc.org.tw; Tel.: +886-7-351-3121 (ext. 2507)
}

Received: 18 February 2018; Accepted: 8 May 2018; Published: 11 May 2018

\begin{abstract}
In this study, an optimal selective laser melting (SLM) process for manufacturing dense NiTi alloy with pseudoelasticity and shape-memory capability was proposed. The microstructure, phase-transformation temperature, shape memory capability, and pseudoelasticity were investigated by scanning electron microscopy, $\mathrm{X}$-ray diffraction, differential scanning calorimetry, and bending and tensile tests. NiTi powder with a particle size $>45 \mu \mathrm{m}$ was selected for the subsequent SLM process, because it exhibited a Ni/Ti ratio of $\sim 1$ and a lower oxygen content than powders with smaller particle sizes. A thin-walled disk ( $0.48 \mathrm{~mm}$ thick) and cuboid samples $(5 \mathrm{~mm}$ thick) were prepared for investigating the variation in the homogeneity of the microstructure. The thin-walled SLM-NiTi sample exhibited a marginally inhomogeneous microstructure between layers, and defects existed in the previously formed side. The cuboid SLM-NiTi sample was fabricated without undesirable secondary phases, and it exhibited a 100\% shape-recovery rate under $2 \%$ bending strain and completely pseudoelastic under 3\% strain. Also, the SLM-NiTi exhibited lower phase-transformation temperatures and a broader phase-transformation range than the original NiTi. The phase-transformation range can be reduced by annealing.
\end{abstract}

Keywords: selective laser melting; NiTi; shape memory; pseudoelasticity

\section{Introduction}

NiTi alloys have pseudoelasticity, shape-memory capability [1], remarkable corrosion resistance [2], low elastic modulus [3], and non-ferromagnetic property [4]. They are widely used in various biomedical engineering applications, such as orthodontic arch wires, surgical stents, active catheters, spine-fracture fixations, oral and maxillofacial implants, bone plates, and lumbar vertebral replacements. However, the specific mechanical properties of NiTi render its machining a challenging task. The drawbacks in machining NiTi include high tool wear, undesirable chip formation, and burr formation [5]. Non-traditional machining processes have been established in order to be more effective alternatives to manufacture NiTi products, such as laser cutting and electric discharge machining. However, laser cutting and electric discharge machining parts require further steps to remove heat-affected zones and recast layers, respectively [6,7]. Powder metallurgy allows the shaping of powder materials without machining or plastic deformation. However, NiTi parts that were sintered from powders are porous and may contain other intermetallic phases of $\mathrm{Ti}_{2} \mathrm{Ni}$ and $\mathrm{TiNi}_{3}$ [8]. In addition, it is challenging to fabricate complex geometries using powder metallurgy. 
Recently, metal additive manufacturing has been developed for metal products, which is fundamentally an electron-beam or laser-melting process that is applied to metallic powder. Powder-bed based system, such as selective laser melting (SLM) [9] and powder-fed systems, known as laser cladding $[10,11]$, were available today. SLM technique exhibits the advantage of convenient fabrication of complex-shaped products from a computer-aided design (CAD) file. Based on computer numerical control system, hybrid manufacturing technology, such as laser melting, laser polishing, and milling operations were developed [12]. Moreover, the internal architecture of the components can be adjusted, which renders the process suitable for manufacturing porous structures. Research on porous SLM-NiTi parts has been conducted $[13,14]$, and such components exhibit shape-memory capability $[13,14]$ and functional stability [13].

Although porous SLM-NiTi samples maintain adequate mechanical properties, Ni-ion release by these samples is higher than that by the dense samples in a cell-culture medium [15]. Studies on cell cultures have shown that Ni ions exert cytotoxic effects, such as breakage of DNA strands, damage to DNA base [16], and suppression of DNA lesion repair [17]. Recently, researchers have attempted to fabricate dense SLM-NiTi. However, these samples frequently contain intermetallic phases $\left(\mathrm{Ti}_{2} \mathrm{Ni}\right.$ and $\left.\mathrm{Ni}_{4} \mathrm{Ti}_{3}\right)$ or oxides $\left(\mathrm{TiO}_{2}\right.$ and $\left.\mathrm{Ti}_{4} \mathrm{Ni}_{2} \mathrm{O}\right)$, owing to the use of a low scanning velocity $[18,19]$ or high energy density [20]. These intermetallic compounds and oxides inhibit phase transformation, which deteriorates the shape-memory capability and pseudoelasticity of the samples. To prevent second-phase precipitation, adequate regulation of the SLM process parameters is required.

This study aimed to achieve dense NiTi samples without the formation of undesirable phases by adjusting the energy density. The sample shows shape-memory capability and pseudoelasticity. First, an applicable powder particle size was selected for use in SLM based on the powder composition (low oxygen content and $\mathrm{Ni} / \mathrm{Ti}$ of $\sim 1$ ). Subsequently, two types of dense samples, thin-walled disks, and cuboids were fabricated for inspecting the effects of sample thickness on the microstructural homogeneity. Finally, the microstructure, shape-memory capability, and pseudoelasticity of the SLM-NiTi samples were evaluated.

\section{Materials and Methods}

Pre-alloyed $\mathrm{Ni}_{50} \mathrm{Ti}_{50}$ powder (LPW Technology Ltd., Runcorn, UK) with a particle size between $\mathrm{d}_{10}=20 \mu \mathrm{m}$ and $\mathrm{d}_{90}=45 \mu \mathrm{m}$ was used (Figure 1a); its composition is listed in Table 1. Two types of SLM-NiTi samples, thin-walled disks and cuboid samples, were prepared using a commercial SLM system (AMP-250, Tongtai, Kaohsiung, Taiwan) under argon atmosphere. Scan strategy was illustrated in Figure 1b. A layer thickness of $50 \mu \mathrm{m}$ and hatch spacing of $130 \mu \mathrm{m}$ were used. The samples were built on a baseplate Iconel 718 alloy that was preheated to $700{ }^{\circ} \mathrm{C}$. The thin-walled disk sample had a diameter of $10 \mathrm{~mm}$ and a thickness of $0.48 \mathrm{~mm}$, as illustrated in Figure 1c. This sample was prepared for investigating the variation in the microstructure on the front and back sides of the sample.

Table 1. Chemical composition of the received NiTi-powder.

\begin{tabular}{cccccc}
\hline Element & $\mathbf{T i}$ & $\mathbf{N i}$ & $\mathbf{O}$ & $\mathbf{C}$ & $\mathbf{N}$ \\
\hline Composition $(\mathrm{wt} \%)$ & 45.52 & 54.34 & 0.101 & 0.033 & 0.006 \\
\hline
\end{tabular}

The cuboid samples had dimensions of $10 \times 10 \times 5 \mathrm{~mm}^{3}$, as illustrated in Figure $1 \mathrm{~d}$. They were manufactured using four different energy densities that were described by two parameters: coupling power $(225,212,200$, and $175 \mathrm{~W})$ and scanning velocity $(850,785,720$, and $500 \mathrm{~mm} / \mathrm{s})$. The cuboids were manufactured with linear laser energy densities of $40.7,41.6,42.7$, and $53.9 \mathrm{~J} / \mathrm{mm}^{3}$, which were estimated by Equation (1). In the equation, $P, h, d$, and $v$ correspond to the laser power, hatch spacing, layer thickness, and scanning velocity, respectively.

$$
E=P / h \times d \times v
$$


The various phases of the NiTi powder and the SLM-NiTi samples were characterized by powder X-ray diffractometry (XRD, Model 2200, Rigaku Co., Tokyo, Japan). Monochromatic $\mathrm{Cu} \mathrm{K} \alpha$ radiation was used at operating values of $40 \mathrm{kV}$ and $30 \mathrm{~mA}$. The XRD data were collected over a $2 \theta$ range of $20-80^{\circ}$, with a step-size of $0.04^{\circ}$ / step and a count time of $5 \mathrm{~s}$. Samples for metallographic examinations were prepared by grounding, polishing, and etching in a water solution containing $5 \% \mathrm{HNO}_{3}$ and $3 \% \mathrm{HF}$ for $6 \mathrm{~s}$. The etched microstructure was examined using an optical microscope (OM, Olympus, Tokyo, Japan). The morphology and composition of the SLM-NiTi sample were examined by a scanning electron microscope (SEM, JSM-6330TF, JEOL, Tokyo, Japan), equipped with an energy dispersive X-ray spectroscope (EDS, JEOL). The phase-transformation behavior of the SLM-NiTi sample as a function of temperature was evaluated by differential scanning calorimetry (DSC, Q10, TA Instruments, New Castle, DE, USA), with a regulated heating/cooling rate of $10^{\circ} \mathrm{C} / \mathrm{min}$. A sample of approximately $30 \mathrm{mg}$ weight was sliced from the SLM-NiTi sample for DSC analysis. The Ra surface roughness of the sample surface was measured using a surface profilometer (SJ-400, Mitutoyo, Kawasaki City, Japan), and the average of a minimum of five test readings was considered. The shape-memory capability was examined by conducting a bending test [21]. The SLM-NiTi sample was loaded in a liquid-nitrogen bath to ensure that it underwent complete transformation to the martensite phase. The SLM-NiTi sample was bent to a $2 \%$ bending strain ( $\varepsilon$, according to Equation (2)) under the load, as illustrated in Figure 2. After bending, the sample was removed from the fixture, and then $\theta_{f}$ was measured at a temperature that was above the austenite finish temperature $\left(A_{\mathrm{f}}\right)$. The shape-recovery rate $\left(R_{\mathrm{SME}}\right)$ was calculated, according to the following Equation (3).

$$
\begin{gathered}
\varepsilon=T / 2 R \\
R_{\mathrm{SME}}=\left(\theta_{i}-\theta_{f}\right) / \theta_{i}
\end{gathered}
$$

Pseudoelasticity was evaluated by tensile testing, which was performed in a cyclic manner with a constant testing speed of $0.25 \mathrm{~mm} / \mathrm{min}$ by means of a universal testing machine. Before testing, the sample was heated to above $A_{\mathrm{f}}$ to ensure that the sample has a primarily austenitic phase.

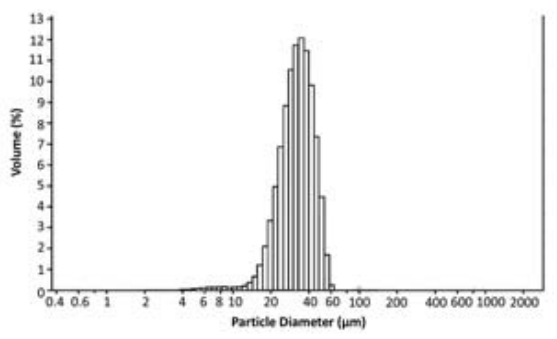

(a)

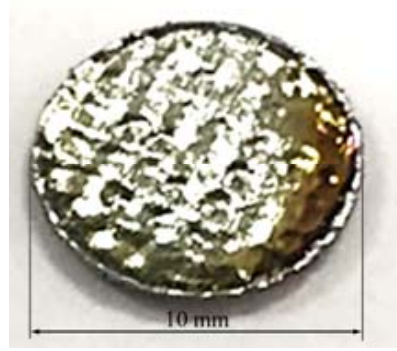

(c)

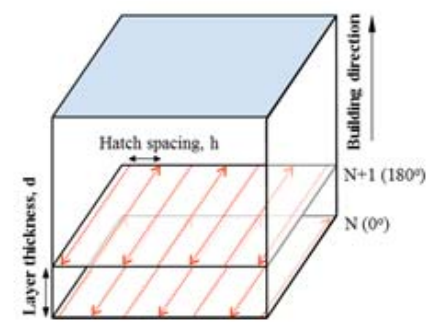

(b)

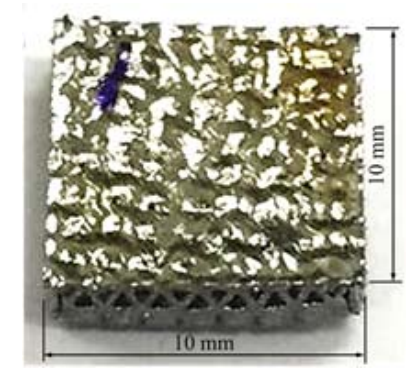

(d)

Figure 1. (a) Particle distribution of the NiTi powder; (b) Illustration of scan strategy of the selective laser melting (SLM) process; (c) Thin-wall disk of thickness $0.48 \mathrm{~mm}$; and, (d) the cuboid sample of thickness $5 \mathrm{~mm}$. 


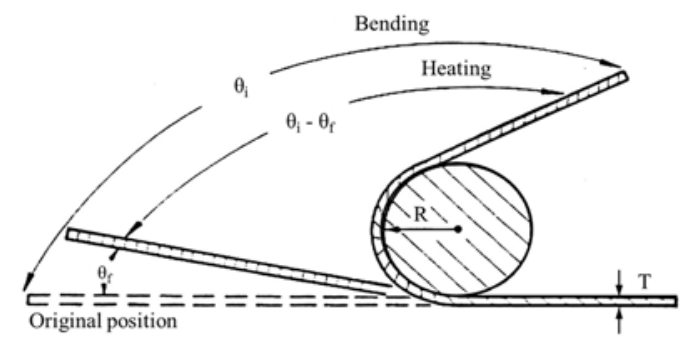

Figure 2. Schematic diagram of measurement of shape-recovery rate by bending test.

\section{Results and Discussion}

\subsection{Composition and Microstructure of NiTi Powder}

Figure $3 a, b$ illustrate the morphologies of the NiTi powder with particle sizes $>45 \mu \mathrm{m}$ and $<25 \mu \mathrm{m}$, respectively. The EDS results indicated that the powder with larger particles $(>45 \mu \mathrm{m})$ was more favorable for minimizing the oxygen content than that with smaller particles $(<25 \mu \mathrm{m})$. In addition, the former exhibited a Ni/Ti atomic ratio that was closer to 1 . The NiTi powder with smaller particles exhibited a smaller grain size than that with larger particle particles, as illustrated in Figure 3c,d. Numerous grain boundaries provided more diffusion paths for the oxygen to react with the NiTi particle surfaces, thus confirming the higher oxygen content of the powder with smaller particles. Therefore, this study used the powder with a particle size $>45 \mu \mathrm{m}$ for the subsequent SLM. Figure 4 illustrates the XRD spectra of the NiTi powder with particle sizes $<25,25-45$, and $>45 \mu \mathrm{m}$. All of the powders consisted of B19' and B2 phases. Furthermore, the B19' peak (021) exhibited higher intensity than the B2 peak $(-110)$.

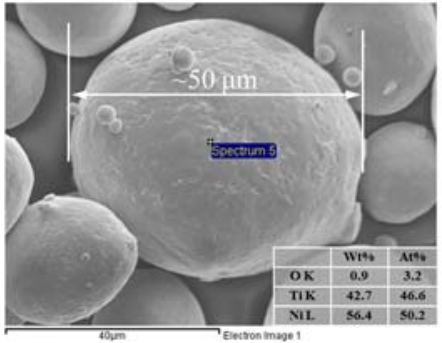

(a)

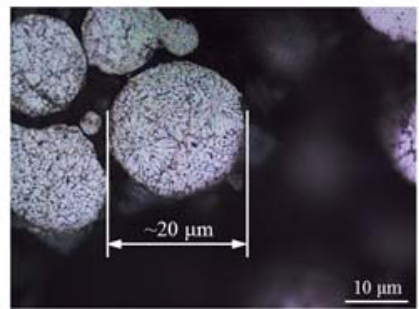

(c)

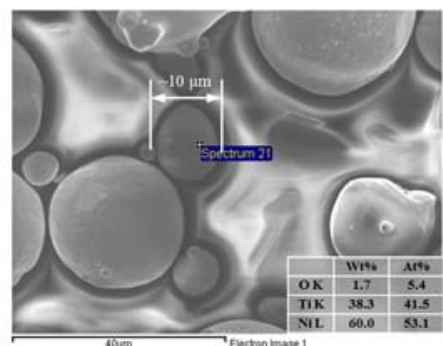

(b)

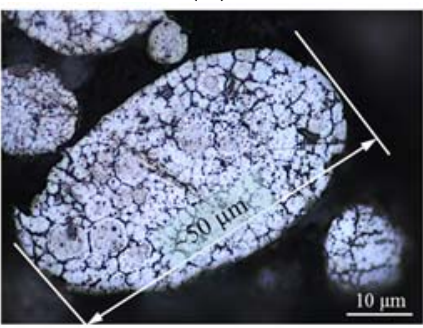

(d)

Figure 3. Scanning electron microscope (SEM) micrograph of NiTi powder of particle sizes (a) $>45 \mu \mathrm{m}$ and $(\mathbf{b})<25 \mu \mathrm{m}$. Optical microscope (OM) image of the NiTi powder of particle sizes (c) $>45 \mu \mathrm{m}$ and (d) $<25 \mu \mathrm{m}$. 


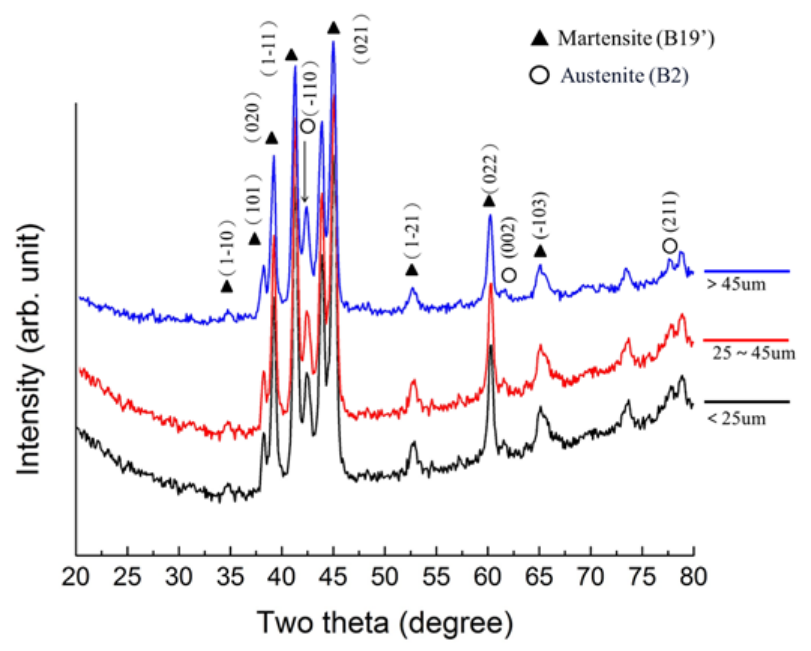

Figure 4. X-ray diffractometry (XRD) spectra of NiTi powder with particle sizes of $<25 \mu \mathrm{m}, 25-45 \mu \mathrm{m}$, and $>45 \mu \mathrm{m}$.

\subsection{Composition and Microstructure of Thin-Wall Samples}

The thin-walled sample had a thickness of $0.48 \mathrm{~mm}$ (Figure 1b), which was approximately equivalent to 10 vertically stacked NiTi particles. Figure 5a illustrates the front of the thin-walled sample, which mainly consisted of equiaxed grains. Further, both columnar and equiaxed grains constitute the back of this sample, as illustrated in Figure $5 \mathrm{~b}$. In addition, many cracks and pores were observed (Figure $5 \mathrm{c}$ ). The defect formation resulted from the rapid cooling at the back of the sample, owing to its direct contact with the substrate. Under rapid cooling, the molten pool was maintained in its molten state for a very short period, which prevented the complete elimination of pores between the NiTi particles. Moreover, columnar grains resulted from directional solidification at the face of the sample in contact with the substrate. Furthermore, the rapid cooling caused the back of the sample to exhibit a similar composition (Ni/Ti ratio and phase) as the NiTi powder (Table 2).

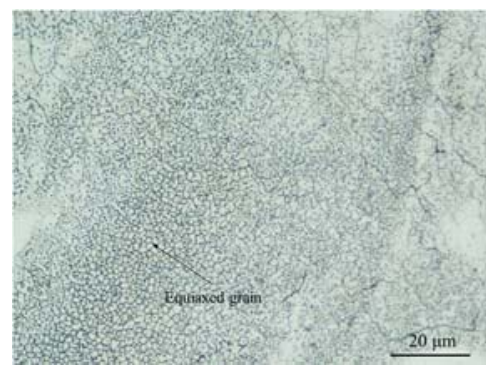

(a)

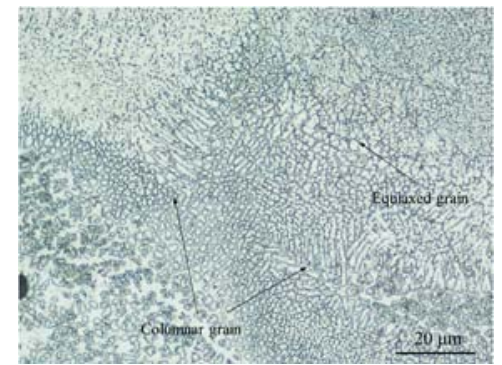

(b)

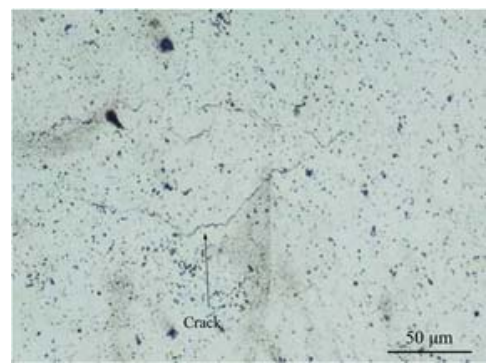

(c)

Figure 5. OM images of (a) front of thin-wall sample and (b) and (c) back of the thin-wall sample.

Table 2. Composition, phase, and surface roughness of the front and back surfaces of the thin-wall disk.

\begin{tabular}{cccc}
\hline & Front Surface & Back Surface & NiTi Powder \\
\hline $\mathrm{Ti}(\mathrm{wt} \%)$ & $34.3 \pm 1.7$ & $40.9 \pm 4.7$ & 45.5 \\
$\mathrm{Ni}(\mathrm{wt} \%)$ & $64.5 \pm 1.9$ & $53.9 \pm 2.6$ & 54.4 \\
$\mathrm{O}(\mathrm{wt} \%)$ & $1.2 \pm 0.8$ & $5.2 \pm 2.3$ & 0.1 \\
Phase & $\mathrm{B} 2$ & $\mathrm{~B} 19^{\prime}+\mathrm{B} 2$ & $\mathrm{~B} 19^{\prime}+\mathrm{B} 2$ \\
Ra Roughness $(\mu \mathrm{m})$ & 3.44 & 7.16 & - \\
\hline
\end{tabular}

The results indicated that the SLM thin-walled sample exhibited marginally inhomogeneous compositions and properties between layers. This phenomenon was noteworthy for fabricating 
thin-walled NiTi product, owing to the high sensitivity of the phase-transformation behavior of NiTi to its composition. Cuboid samples with a thickness of $5 \mathrm{~mm}$ were fabricated to prevent the existence of inhomogeneous properties in the SLM samples, and the following investigation focuses on these cuboid samples.

\subsection{Effect of Laser Energy Density on Composition and Microstructure of Cuboid Samples}

Figure 6 illustrates the SEM micrograph of a top surface of the cuboid sample perpendicular to the building direction. The laser passage strips were evident on the sample that was fabricated using a high energy density (Figure 6a). Increasing the scanning velocity was beneficial for rendering the strips invisible. The section of the cuboid sample perpendicular to the building direction was also observed. In Figure 7a, the dotted line indicated the laser passage direction, and it refers to the alternating laser route with a spacing of $130 \mu \mathrm{m}$. In addition, few defects in the form of small pores of a size less than $1 \mu \mathrm{m}$ are apparent in Figure $7 \mathrm{~b}$.

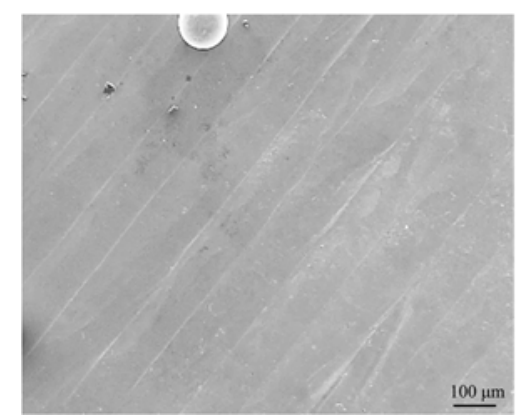

(a)

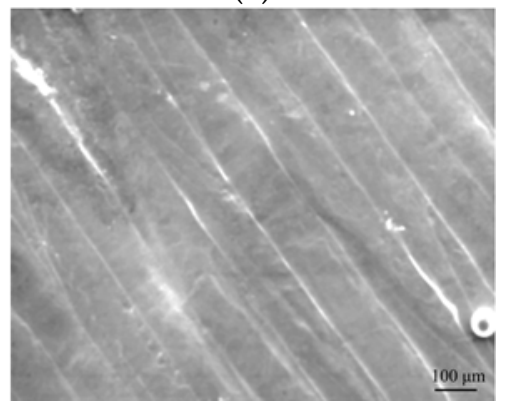

(c)

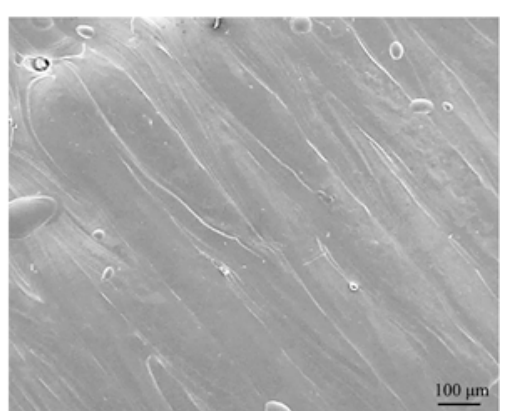

(b)

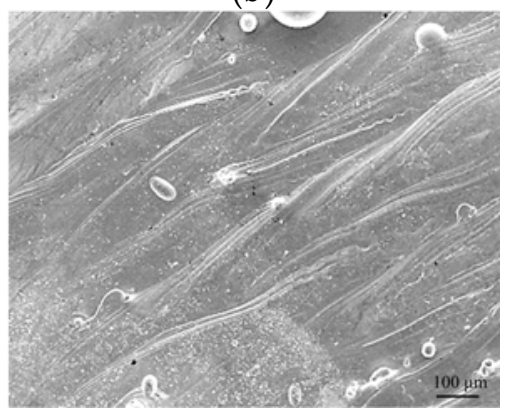

(d)

Figure 6. SEM micrographs of SLM-NiTi sample fabricated with a powder density of (a) 40.7; (b) 41.6; (c) 42.7 ; and, (d) $53.9 \mathrm{~J} / \mathrm{mm}^{3}$.

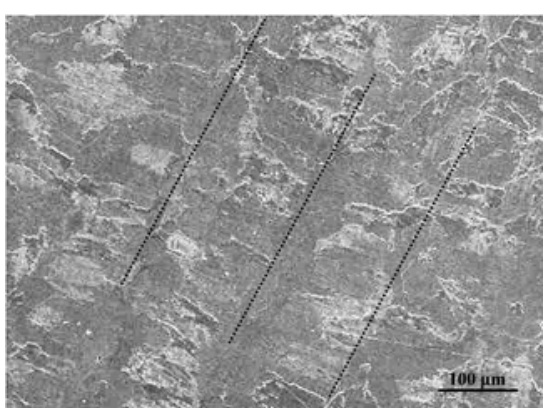

(a)

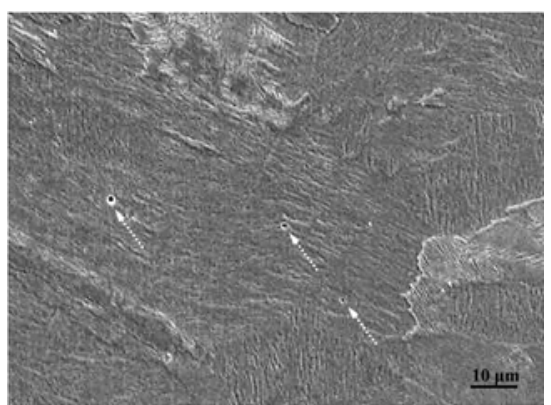

(b)

Figure 7. (a) SEM micrograph of SLM-NiTi sample fabricated with a power density of $42.7 \mathrm{~J} / \mathrm{mm}^{3}$; and, (b) High-magnification view of (a). 
Figure 8 depicts the surface roughness as a function of energy density. The roughness of the sample first decreased with an increased power density to $42.7 \mathrm{~J} / \mathrm{mm}^{3}$, and it then increased with an increasing power density. A very high energy density $\left(53.9 \mathrm{~J} / \mathrm{mm}^{3}\right)$ resulted in the particular sample exhibiting the highest surface roughness among all of the samples.

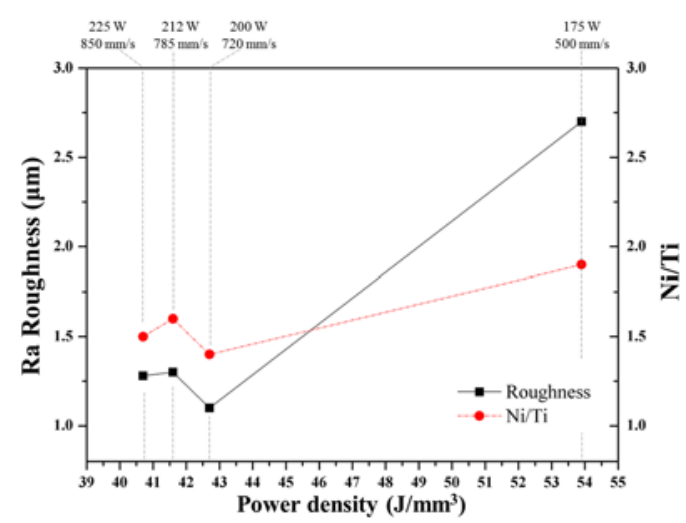

Figure 8. Surface roughness and Ni/Ti ratio of the SLM sample as a function of power density.

Previous studies suggested that the roughness of the sample that was achieved by laser processing depended on two fluid flow patterns in the melt pool, damped capillary oscillations, and thermocapillary flows, which occurred at relatively low and high laser-energies, respectively [22,23]. From Figure 8, in the power density range $40.7-42.7 \mathrm{~J} / \mathrm{mm}^{3}$, the surface roughness decreased with an increasing energy density, and this region is regarded as dominated by capillary oscillation. In this region, an increased melting duration resulted in surface capillary waves being more significantly damped [22,23]. However, as the energy increased beyond $42.7 \mathrm{~J} / \mathrm{mm}^{3}$, the roughness increased with increasing energy density because thermocapillary flows dominated the melt pool [24-26]. The increased roughness was due to ripples induced by the thermocapillary flows when the energy density was increased.

The Ni/Ti ratio of the SLM sample is shown in Figure 8. The sample that was fabricated using a high energy density $\left(53.9 \mathrm{~J} / \mathrm{mm}^{3}\right)$ exhibited a Ni/Ti ratio that varied significantly from that of the original NiTi-powder. The variations in the composition were due to the oxidation or metal evaporation occurring during the laser process [20]. In this study, the oxygen content of the SLM-sample increased with an increasing power density. A higher power density induced a high melt-pool temperature and long melting duration. The high melt-pool temperature caused the metal liquid to violently react with oxygen in air. The long melting duration allowed for the metal liquid to remain in contact with the atmosphere. Among the samples that were fabricated at various energy densities, the one that was fabricated at $42.7 \mathrm{~J} / \mathrm{mm}^{3}$ exhibited a $\mathrm{Ni} / \mathrm{Ti}$ ratio closest to 1 and the lowest surface roughness. The following section provides a detailed analysis of this sample.

\subsection{Phase and Phase Transformation of SLM-NiTi}

Figure 9a illustrates the XRD spectrum of SLM-NiTi, which shows predominant B2 and minor B19' phases; this spectrum showed a different ratio of B19' to B2 as compared to that of the NiTi powders. The high energy of the laser heated the NiTi powders (B19' and B2) and led to the appearance of the B2 phase at high temperatures. During the cooling process, a rapid cooling rate promoted the stabilization of the B2 phase. After annealing at $850{ }^{\circ} \mathrm{C}$ for $1 \mathrm{~h}$, the relative intensity of the B19' peak to $\mathrm{B} 2$ peak increased (Figure $9 \mathrm{~b}$ ). This result indicated that the post-annealed SLM-NiTi sample exhibited a phase that was similar to that of the original NiTi. In conclusion, the fabricated SLM-NiTi in this study had the same phases as the received NiTi-powder, and no undesirable precipitations were formed. This was because a relatively high scanning velocity $(500-850 \mathrm{~mm} / \mathrm{s})$ was used when compared to that used in other studies. Previously, precipitations, such as $\mathrm{Ti}_{2} \mathrm{Ni}_{1} \mathrm{Ni}_{4} \mathrm{Ti}_{3}$ or $\mathrm{TiNi}_{2} \mathrm{Ox}$ were observed 
when SLM-NiTi was fabricated at a relatively low scanning velocity $(<200 \mathrm{~mm} / \mathrm{s}[18],<180 \mathrm{~mm} / \mathrm{s}[19]$, and $<170 \mathrm{~mm} / \mathrm{s}[20])$.

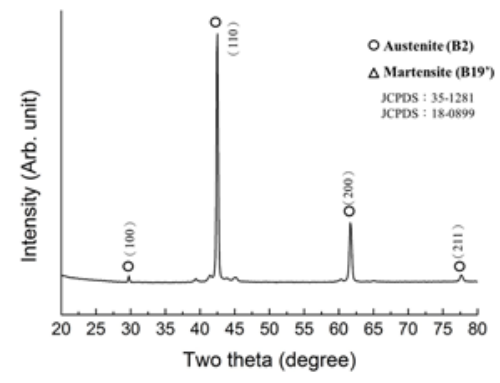

(a)

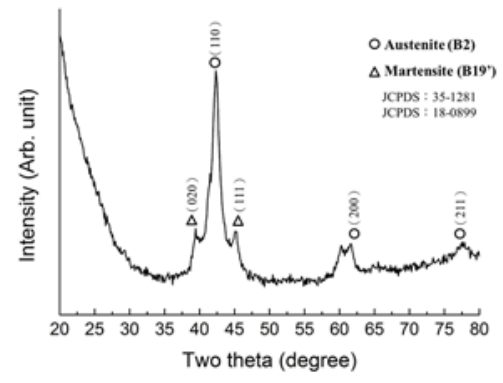

(b)

Figure 9. XRD spectrum of (a) SLM-NiTi sample fabricated with a power density of $42.7 \mathrm{~J} / \mathrm{mm}^{3}$, and (b) SLM-NiTi sample after annealing at $850^{\circ} \mathrm{C}$ for $1 \mathrm{~h}$.

The phase-transformation temperatures that were measured by DSC are listed in Table 3. For the SLM sample, the martensite peak temperature $\left(M^{*}\right)$ and the austenite peak temperature $\left(A^{*}\right)$ were $-10.2^{\circ} \mathrm{C}$ and $71.7^{\circ} \mathrm{C}$, respectively. For the original $\mathrm{NiTi}$, the $\mathrm{M}^{*}$ and $A^{*}$ values were $50.3^{\circ} \mathrm{C}$ and $91.0^{\circ} \mathrm{C}$, respectively. The SLM-NiTi sample had a lower phase-transformation temperature and broader transformation range than the original NiTi. The broad transformation range implied that the transformation was inhibited, owing to thermal defects that were induced by rapid cooling. After annealing at $850{ }^{\circ} \mathrm{C}$ for $1 \mathrm{~h}$, the martensite-transformation temperature increased and the transformation range narrowed (Table 3), implying that annealing was required to render the phase-transformation characteristics of the SLM-NiTi sample similar to that of the original NiTi.

Table 3. Transformation temperatures of cuboid SLM-NiTi sample with and without annealing at $850{ }^{\circ} \mathrm{C}$ for $1 \mathrm{~h}$.

\begin{tabular}{ccc}
\hline & SLM-TiNi & SLM-TiNi after Annealing at $850{ }^{\circ} \mathbf{C}$ for $\mathbf{1 ~ h}$ \\
\hline$M^{*}\left({ }^{\circ} \mathrm{C}\right)$ & -10.18 & 4.71 \\
$A^{*}\left({ }^{\circ} \mathrm{C}\right)$ & 71.66 & 60.1 \\
Phase $\left(25^{\circ} \mathrm{C}\right)$ & $\mathrm{B} 19^{\prime}+\mathrm{B} 2$ & $\mathrm{~B} 19^{\prime}+\mathrm{B} 2$ \\
\hline
\end{tabular}

The lowering of the phase-transformation temperatures of SLM-NiTi was also observed in a previous study [27]. The transformation temperature is sensitive to the NiTi composition and it depends on the $\mathrm{Ni} / \mathrm{Ti}$ ratio [28,29]. A high $\mathrm{Ni} / \mathrm{Ti}$ ratio results in an increased the transformation temperature, whereas a low $\mathrm{Ni} / \mathrm{Ti}$ ratio results in a decreased temperature.

Olier et al. indicated that the lowering of the phase-transformation temperatures of NiTi was attributed to an increased amount of impurities [30]. Major impurities, like air, $\mathrm{N}_{2}, \mathrm{O}_{2}$, and $\mathrm{CO}_{2}$ were likely to induce precipitation in $\mathrm{NiTi}$ to form compounds, such as $\mathrm{Ti}(\mathrm{C}, \mathrm{N})$ and $\mathrm{Ti}_{4} \mathrm{Ni}_{2} \mathrm{O}$, particularly in a high-temperature process. According to the precipitate stoichiometry, the precipitation reactions resulted in a deficiency of $\mathrm{Ti}$ in the NiTi matrix. In effect, oxidation, nitridation, and carbonation reactions induced an increase in $\mathrm{Ni}$ in NiTi solid solutions, which caused the phase-transformation temperature to decrease.

In contrast to the results of this study, some studies reported that the laser process induced an increase in the phase-transformation temperature. In addition, the phase-transformation temperature increased with increasing the applied energy density of the applied laser [20,31,32], because of Ni evaporation during the high-temperature process. This phenomenon has been frequently observed in laser-welded NiTi $[33,34]$ and SLM-NiTi $[20,32,35]$. 


\subsection{Shape Memory Capability and Pseudoelasticity of SLM-NiTi}

Figure 10 illustrates loading-unloading curves of the SLM-NiTi tensile test sample, which showed that SLM-NiTi exhibited pseudoelasticity in the austenite phase. Negligible residual strain was observed under relative strain of $0.5,2.0$, and 3.0\%. However, when the SLM-NiTi sample was strained up to $4.0 \%$, it exhibited a $0.9 \%$ residual strain after relief. Accordingly, the SLM-NiTi sample exhibited complete shape recovery under 3.0\% strain. Finally, the shape-recovery rate of the SLM-NiTi wire was measured. The SLM-NiTi wire was first cooled by immersion in liquid nitrogen to form the martensite phase, and was then bent to a specific angle, as illustrated in Figure 2. The bent SLM-NiTi wire was then recovered at a temperature above $A_{\mathrm{f}}$, and the shape-recovery rates were calculated using Equation (1). The shape-recovery rate of the SLM-NiTi wire was $100 \%$, which was equivalent to that of the NiTi wire that was formed by vacuum arc-melting.

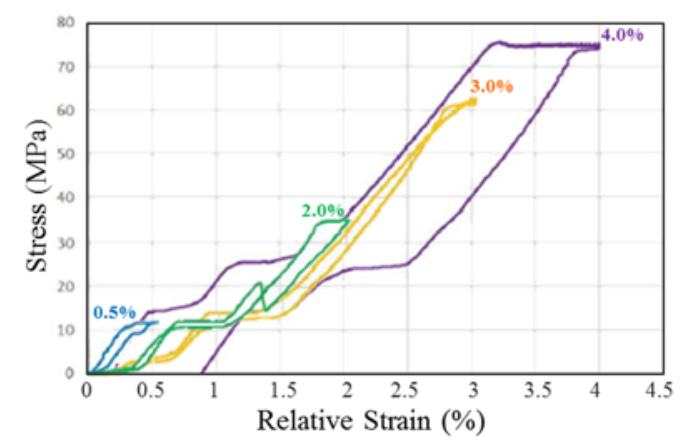

Figure 10. Loading-unloading curves of SLM-NiTi tensile test specimen that was fabricated with a power density of $42.7 \mathrm{~J} / \mathrm{mm}^{3}$.

\section{Conclusions}

This study aimed to achieve dense NiTi samples without undesirable phases and with shape-memory capability and pseudoelasticity by suitably regulating SLM, including the suitable selection of the powder- and laser-parameters.

1. NiTi powder with larger particles exhibited lower oxygen content than that with smaller particles.

2. The thin-walled NiTi sample that wsa fabricated by SLM exhibited a marginally inhomogeneous microstructure between layers. In this sample, cracks and pores were frequently observed on the face of the sample in contact with the substrate.

3. High energy density $\left(53.9 \mathrm{~J} / \mathrm{mm}^{3}\right)$ resulted in the sample exhibiting a high surface roughness and $\mathrm{a} \mathrm{Ni} / \mathrm{Ti}$ ratio that was varying significantly from that of the original NiTi powder.

4. SLM-NiTi exhibited a lower phase-transformation temperature and broader transformation range than the original NiTi. The transformation range can be reduced by annealing at $850{ }^{\circ} \mathrm{C}$ for $1 \mathrm{~h}$.

5. SLM-NiTi exhibited pseudoelasticity under 3.0\% strain. The shape-recovery rate of the SLM-NiTi wire was $100 \%$ under $2 \%$ bending strain, which was equivalent to that of the NiTi wire that was formed by vacuum arc-melting.

Author Contributions: Shih-Fu Ou and Meng-Hsiu Tsai conceived and designed the experiments. Yi-Cheng Chen performed the experiments. Shih-Fu Ou and Bou-Yue Peng analyzed the data.

Acknowledgments: The authors acknowledge with pleasure the financial support of this work by the Ministry of Science and Technology, Taiwan, R.O.C under Grant No. 105-2221-E-151 -021-MY2.

Conflicts of Interest: The authors declare no conflicts of interest. 


\section{References}

1. Yoneyama, T.; Doi, H.; Hamanaka, H.; Okamoto, Y.; Mogi, M.; Miura, F. Super-elasticity and thermal behavior of Ni-Ti alloy orthodontic arch wires. Dent. Mater. J. 1992, 11, 1-10. [CrossRef] [PubMed]

2. Liu, Y.; Xiang, H. Apparent modulus of elasticity of near-equiatomic NiTi. J. Alloys Compd. 1998, 270, 154-159. [CrossRef]

3. Wever, D.J.; Veldhuizen, A.G.; de Vries, J.; Busscher, H.J.; Uges, D.R.A.; van Horn, J.R. Electrochemical and surface characterization of a nickel-titanium alloy. Biomaterials 1998, 19, 761-769. [CrossRef]

4. Duerig, T.; Pelton, A.; Stockel, D. An overview of nitinol medical applications. Mater. Sci. Eng. A 1999, 273, 149-160. [CrossRef]

5. Weinert, K.; Petzoldt, V. Machining of NiTi based shape memory alloys. Mater. Sci. Eng. A 2004, 378, $180-184$. [CrossRef]

6. Wu, M.H. Fabrication of NiTi materials and components. Mater. Sci. Forum 2002, 394-395, 285-292. [CrossRef]

7. Lin, H.C.; Lin, K.M.; Cheng, I.S. The Electro-discharge machining characteristics of TiNi shape memory alloys. J. Mater. Sci. 2001, 36, 399-404. [CrossRef]

8. Igharo, M.; Wood, J.V. Compaction and Sintering Phenomena in Titanium-Nickel Shape Memory Alloys. Powder Metall. 1985, 28, 131-139. [CrossRef]

9. Vandenbroucke, B.; Kruth, J.P. Selective laser melting of biocompatible metals for rapid manufacturing of medical parts. Rapid Prototyp. J. 2006, 13, 148-159. [CrossRef]

10. Calleja, A.; Tabernero, I.; Fernández, A.; Celaya, A.; Lamikiz, A.; López de Lacalle, L.N. Improvement of strategies and parameters for multi-axis laser cladding operations. Opt. Lasers Eng. 2014, 56, 113-120. [CrossRef]

11. Calleja, A.; Tabernero, I.; Ealo, J.A.; Campa, F.J.; Lamikiz, A.; López de Lacalle, L.N. Feed rate calculation algorithm for the homogeneous material deposition of blisk blades by 5-axis laser cladding. Int. J. Adv. Manuf. Technol. 2014, 74, 1219-1228. [CrossRef]

12. Rosa, B.; Mognol, P.; Hascoët, J.Y. Laser polishing of additive laser manufacturing surfaces. J. Laser Appl. 2015, 27, S29102. [CrossRef]

13. Dadbakhsh, S.; Speirs, M.; Kruth, J.P.; van Humbeeck, J. Influence of SLM on shape memory and compression behaviour of NiTi scaffolds. CIRP Ann. Manuf. Tech. 2015, 64, 209-212. [CrossRef]

14. Andani, M.T.; Saedi, S.; Turabi, A.S.; Karamooz, M.R.; Haberland, C.; Karaca, H.E.; Elahinia, M. Mechanical and shape memory properties of porous $\mathrm{Ni}_{50.1} \mathrm{Ti}_{49.9}$ alloys manufactured by selective laser melting. J. Mech. Behav. Biomed. Mater. 2017, 68, 224-231. [CrossRef] [PubMed]

15. Habijan, T.; Haberland, C.; Meier, H.; Frenzel, J.; Wittsiepe, J.; Wuwer, C.; Greulich, C.; Schildhauer, T.A.; Köller, M. The biocompatibility of dense and porous Nickel-Titanium produced by selective laser melting. Mater. Sci. Eng. C 2013, 33, 419-426. [CrossRef] [PubMed]

16. Liang, R.; Senturker, S.; Shi, X.; Bal, W.; Dizdaroglu, M.; Kasprzak, K.S. Effects of Ni(II) and Cu(II) on DNA interaction with the N-terminal sequence of human protamine P2: Enhancement of binding and mediation of oxidative DNA strand scission and base damage. Carcinogenesis 1999, 20, 893-898. [CrossRef] [PubMed]

17. Eliades, T.; Zinelis, S.; Papadopoulos, M.A.; Eliades, G.; Athanasiou, A.E. Nickel content of as-received and retrieved NiTi and stainless steel archwires: Assessing the nickel release hypothesis. Angle Orthod. 2004, 74, 151-154. [PubMed]

18. Shishkovsky, I.V.; Yadroitsev, I.A.; Smurov, I.Y. Direct selective laser melting of nitinol powder. Phys. Procedia 2012, 39, 447-454. [CrossRef]

19. Shishkovsky, I.V.; Yadroitsev, I.A.; Smurov, I.Y. Manufacturing three dimensional nickel titanium articles using layer by layer laser melting technology. Technol. Phys. Lett. 2013, 39, 1081-1084. [CrossRef]

20. Bormann, T.; Schumacher, R.; Müller, R.B.; Mertmann, M.; de Wild, M. Tailoring selective laser melting process parameters for NiTi implants. J. Mater. Eng. Perform. 2012, 21, 2519-2524. [CrossRef]

21. Lin, H.C.; Wu, S.K. Strengthening effect on shape recovery characteristic of the equiatomic TiNi alloy. Scr. Metall. Mater. 1992, 26, 59-62. [CrossRef]

22. Perry, T.L.; Werschmoeller, D.; Duffie, N.A.; Li, X.; Pfefferkorn, F.E. Examination of selective pulsed laser micropolishing on microfabricated nickel samples using spatial frequency analysis. J. Manuf. Sci. Eng. 2009, 131, 021002-021011. [CrossRef] 
23. Vadali, M.; Ma, C.; Duffie, N.A.; Li, X.; Pfefferkorn, F.E. Pulsed laser micro polishing: Surface prediction model. J. Manuf. Process. 2012, 14, 307-315. [CrossRef]

24. Pfefferkorn, F.E.; Duffie, N.A.; Li, X.; Vadali, M.; Ma, C. Improving surface finish in pulsed laser micro polishing using thermocapillary flow. CIRP Ann. Manuf. Technol. 2013, 62, 203-206. [CrossRef]

25. Ma, C.; Vadali, M.; Duffie, N.A.; Pfefferkorn, F.E.; Li, X. Melt Pool flow and surface evolution during pulsed laser micro polishing of Ti6Al4V. J. Manuf. Sci. Eng. 2013, 135, 061023-061031. [CrossRef]

26. Ma, C.; Vadali, M.; Li, X.; Duffie, N.A.; Pfefferkorn, F.E. Analytical and experimental investigation of thermocapillary flow in pulsed laser micropolishing. J. Micro Nano Manuf. 2014, 2, 021010-021018. [CrossRef]

27. Meier, H.; Haberland, C.; Frenzel, J. Structural and functional properties of NiTi shape memory alloys produced by selective laser melting. In Innovative Developments in Design and Manufacturing: Advanced Research in Virtual and Rapid Prototyping; Taylor \& Francis Group: London, UK, 2011; pp. 291-296.

28. Khalil-Allafi, J.; Dlouhy, A.; Eggeler, G. $\mathrm{Ni}_{4} \mathrm{Ti}_{3}$-Precipitation During aging of NiTi shape memory alloys and its influence on martensitic phase transformations. Acta Mater. 2002, 50, 4255-4274. [CrossRef]

29. Frenzel, J.; George, E.P.; Dlouhy, A.; Somsen, C.; Wagner, M.F.X.; Eggeler, G. Influence of Ni on martensitic phase transformations in NiTi shape memory alloys. Acta Mater. 2010, 58, 3444-3458. [CrossRef]

30. Olier, P.; Barcelo, F.; Bechade, J.L.; Brachet, J.C.; Lefevre, E.; Guenin, G. Effects of impurities content (oxygen, carbon, nitrogen) on microstructure and phase transformation temperatures of near equiatomic TiNi shape memory alloys. J. Phys. IV 1997, 7, C5-143-C5-148. [CrossRef]

31. Meier, H.; Haberland, C.; Frenzel, J.; Zarnetta, R. Selective laser melting of NiTi shape memory components. In Innovative Developments in Design and Manufacturing: Advanced Research in Virtual and Rapid Prototyping; CRC Press-Taylor \& Francis Group: Boca Raton, FL, USA, 2009; pp. 233-238.

32. Krishna, B.V.; Bose, S.; Bandyopadhyay, A. Laser processing of net-shape NiTi shape memory alloy. Metall. Mater. Trans. A 2007, 38, 1096-1103. [CrossRef]

33. Falvo, A.; Furgiuele, F.M.; Maletta, C. Laser welding of a NiTi alloy: Mechanical and shape memory behavior. Mater. Sci. Eng. A 2005, 412, 235-240. [CrossRef]

34. Tuissi, A.; Besseghini, S.; Ranucci, T.; Squatrito, F.; Pozzi, M. Effect of Nd-YAG laser welding on the functional properties of the Ni-49.6at.\%Ti. Mater. Sci. Eng. A 1999, 273-275, 813-817. [CrossRef]

35. Bormann, T.; Müller, B.; Schinhammer, M.; Kessler, A.; Thalmann, P.; de Wild, M. Microstructure of selective laser melted nickel-titanium. Mater. Charact. 2014, 94, 189-202. [CrossRef] 